\title{
高歯令者破裂脳動脈瘤手術症例の臨床的検討
}

\author{
柴田 裕次, 野垣 秀和, 玉木 紀彦*
}

\section{A Clinical Study of Elderly Patients with Operated Ruptured Cerebral Aneurysm}

\author{
Yuuji Shibata, M.D., Hidekazu Nogaki, M.D., and Norihiko Tamaki, M.D.* \\ Department of Neurosurgery, Toyooka Municipal Hospital, Toyooka, and \\ *Department of Neurosurgery, Kobe University School of Medicine, Kobe, Japan
}

\begin{abstract}
Summary : An increasing number of older patients are receiving neurosurgical treatment. To investigate the clinical features of elderly patients who had aneurysmal subarachnoid hemorrhage (SAH), we reviewed 40 consecutive cases aged 70 years or older operated on for ruptured cerebral aneurysms.
\end{abstract}

Ninety-five percent of the patients were admitted within 3 days after SAH, and $60 \%$ were operated on in the acute stage.

Both the Hunt \& Kosnik grade on admission and Glasgow Outcome Scale (GOS) at discharge were significantly worse in elderly patients than in younger ones. In Grade I - III, there was no significant difference in GOS between the elderly and the young group. But in the Grade IV patients, all elderly ones showed poor clinical outcome (severe disability, persistant vegetative state, or death), whereas $45 \%$ of the young ones showed a good outcome (good recovery or moderate disability). The mortality rate of patients operated on in the acute stage was significantly higher than that in delayed surgery ( $42 \%$ vs. $8 \%$ ), but the overall outcome showed no significant difference between the two groups. In the elderly group, there were fewer anterior communicating artery aneurysms and more vertebrobasilar artery aneurysms than in the young group (n.s.).

As for the relation between the site of aneurysm and the clinical outcome, the elderly patients with distal anterior cerebral artery aneurysm showed a worse outcome than the young ones.

The primary causes of poor outcome of elderly patients were primary brain damage due to the initial SAH and vasospasm, whereas in the young group the latter was the main factor. Primary causes of death included general complications as well as the initial bleeding and vasospasm.

In aneurysmal surgery of elderly patients, deterioration in the central nervous system as well as in other organs should be considered more.
Key words :

- ruptured aneurysm

- elderly

- aneurysm operation

\footnotetext{
公立豊岡病院 脳神経外科, *神戸大学 脳神経外科(受稿日 1995.12.6)〔連絡先： $\mathbf{T} 670$ 姫路市西庄甲 520 兵庫県立姫路循環器病 センター脳神経外科 柴田裕次] [ Mailing address: Yuuji ShiBATA, M.D., Department of Neurosurgery, Hyogo Brain and Heart Center at Himeji, 520 Saishou-Kou, Himeji 670, Japan]
} 
はじめに

高齢化と平均寿命の延びにつれて, 脳神経外科領域にお いても高齢患者の占める割合が増え, 手術をする機会も多 くなっている. 脳動脈瘤患者も例外ではなく, 特にこの 10 年間に飛躍的に増加している ${ }^{13)}$. しかし，その成績は 若年者と比べていまだ不良であり，手術適応，術後管理な どに若年者と違った特別の注意が必要である ${ }^{11)}$.

今回, 直達手術を行った 70 歳以上の高齢者破裂脳動脈 瘤症例 40 例につき, その臨床的特徵を検討し, 若年者と 比較した。

\section{対象および方法}

1990年から 1994年の 5 年間に，クモ膜下出血患者が 167 名入院し，119 例 $(71 \%)$ に脳動脈瘤直達手術が施行された. このうち $34 \%$ にあたる 40 例が 70 歳以上の高齢者であり, これは高齢者クモ膜下出血患者例の $70 \%$ であった.

これら手術症例につき, 入院時 Hunt \& Kosnik grade ${ }^{1)}$ (付帯事項なし), 動脈瘤の部位, および退院時の ADL (Glasgow Outcome Scale (GOS) ${ }^{3)}$ ) などを検討し, 若年 者群 79 例と比較した。 また, 手術時期を急性期 (発症後 3 日以内), 覀急性期 (4 日 加 7 日), 待機 ( 8 日以後) と分 けて検討した。

手術適応は, 80 歳までを目安とし, Hunt \& Kosnik Grade IV な゙としているが，大きな脳内血腫を伴う例や， 入院後意識状態に改善が認められた例では, 例外的に Grade Vでも手術された。手術に至らなかった理由は, Grade V 8 例, 全身状態不良 5 例, 高齢 3 例, 脳血管攣縮 1 例であった.

\section{結果}

\section{1. 年齢, 性別}

高齢者群は, 70 歳から 80 歳, 平均 74.7 歳で, 男性 10 例, 女性 30 例 (男女比 1 ：3 ) で 38 例 (95\%) は発症後 3 日 以内に入院した.これに対し, 若年者群 79 例は, 37 歳か ら 69 歳, 平均 55.7 歳で, 男性 27 例, 女性 52 例 (男女比 $1: 1.9)$ で，3 日以内の入院は，74 例 (94\%)であった.

\section{2. 入院時重症度と動脈瘤の部位}

入院時 Hunt \& Kosnik grade (Table 1) は, 高齢者群で は Grade I, II : 15 例 $(37.5 \%)$, III : 15 例 $(37.5 \%)$, IV : 8 例 $(20.0 \%), \mathrm{V}: 2$ 例 $(5.0 \%)$ に対し, 若年者群では Grade I, II :47 例 (59.5\%), III : 19 例 (24.1\%), IV :11 例 $(13.9 \%), V: 2$ 例 $(2.5 \%)$ と, 高齢者群で有意に悪かっ た $(p<0.05)$ が，非手術例で若年者の Grade V 患者が多 く, クモ膜下出血患者全体の grade は 2 群に差はなかった.
Table 1 Hunt \& Kosnik grade on admission of operated cases

\begin{tabular}{lccrcc}
\hline \multirow{2}{*}{ Group } & \multicolumn{4}{c}{ Grade } & Total \\
\cline { 2 - 5 } & I, II & III & IV & V & \\
\hline Elderly* & 15 & 15 & 8 & 2 & 40 \\
Young $^{*}$ & 47 & 19 & 11 & 2 & 79 \\
\hline
\end{tabular}

* The grades of elderly group are significantly higher than those of young group. $(p<0.05$, Mann-Whitney's test)

Table 2 Sites of ruptured aneurysms

\begin{tabular}{lrccccc}
\hline Group & IC & Acom & DistalAC & MC & V-B & Total \\
\hline Elderly & 6 & 13 & 3 & 13 & 5 & 40 \\
Young & 15 & 35 & 5 & 22 & 1 & 79 \\
\hline
\end{tabular}

IC: internal carotid artery, Acom: anterior communicating artery, DistalAC: distal anterior cerebral artery, MC: middle cerebral artery, V-B: vertebro-basilar artery.

There are no significant differences in any aneurysmal site between elderly and young group.

Table 3 Glasgow Outcome Scale (GOS) at discharge of operated cases

\begin{tabular}{lcccccc}
\hline \multirow{2}{*}{ Group } & \multicolumn{5}{c}{ GOS } & Total \\
\cline { 2 - 6 } & GR & MD & SD & PVS & D & \\
\hline Elderly* & 10 & 6 & 9 & 4 & 11 & 40 \\
Young* & 39 & 20 & 6 & 1 & 13 & 79 \\
\hline
\end{tabular}

GR: good recovery, MD: moderate disability, SD: severe disability, PVS: persistent vegetative state, D: death. * The GOS of elderly group is significantly worse than that of young group. $(p<0.01$, Mann-Whitney's test)

破裂動脈瘤の部位 (Table 2) は, 高齢者群と若年者群で 差は見られなかったが，高齢者では前交通動脈部に少なく $(33 \%$ と $44 \%)$, 椎骨脳底動脈系に多い $(13 \%$ と $1 \%)$ 傾向 にあった。

\section{3. 退院時 GOS}

高齢者の退院時 GOS (Table 3) は, good recovery (GR) : 10 例 $(25.0 \%)$, moderate disability (MD) : 6 例 $(15.0 \%)$, severe disability (SD) : 9 例 $(22.5 \%)$, persistent vegetative state (PVS) : 4 例 $(10.0 \%)$, death (D) : 11 例 $(27.5 \%)$ で, 若年者群では, GR：39 例 (49.3\%), MD : 20 例 $(25.3 \%), \mathrm{SD}: 6$ 例 $(7.6 \%)$, PVS : 1 例 $(1.3 \%), \mathrm{D}: 13$ 例 $(16.5 \%)$ と, GOS は高齢者群で有意に 悪かった $(p<0.01)$. 入院時 grade ごとに転帰を比較する と, いずれの grade でも高齢者で悪いものの, 有意差はな 


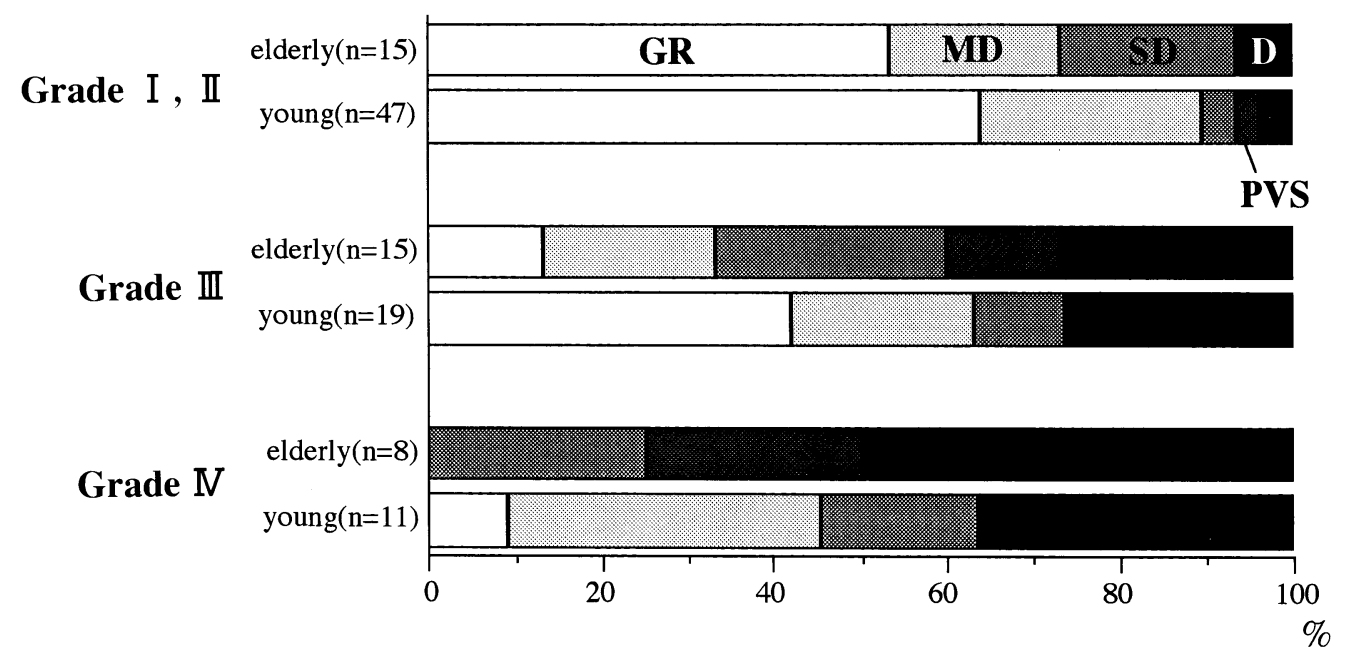

GR: good recovery, MD: moderate disability, SD: severe disability, PVS: persistent vegetative state, D: death.

Fig. 1 Distribution of Glasgow Outcome Scale at discharge according to Hunt \& Kosnik grade on admission

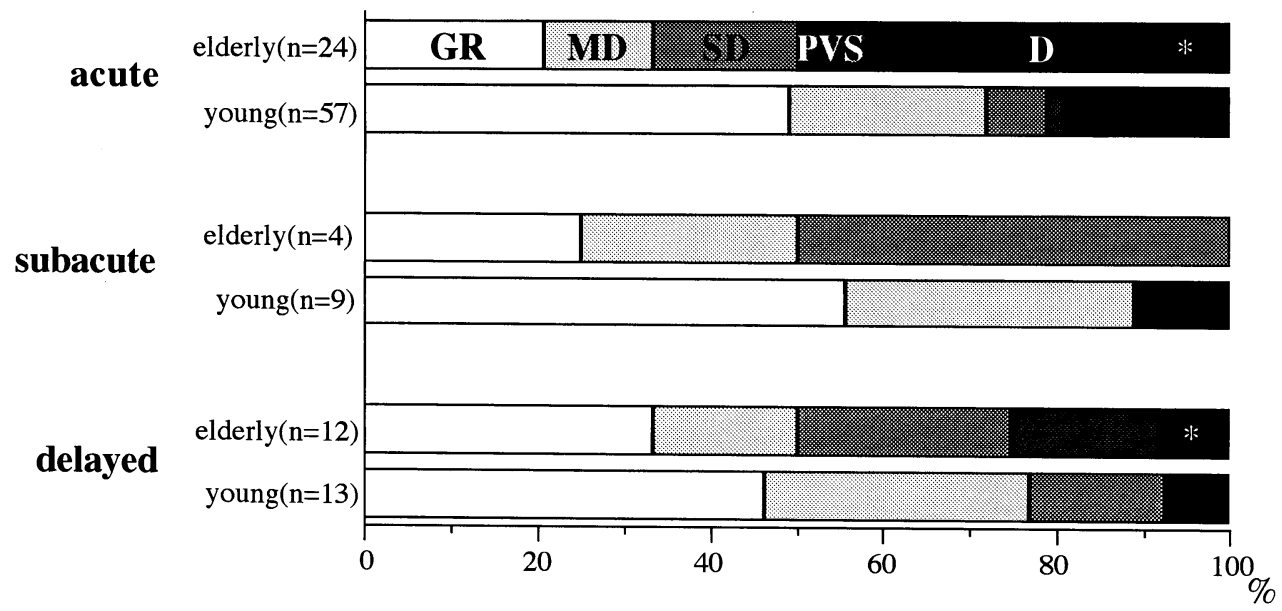

Opertive period --- acute:0-3rd day, subacute:4-7th day, delayed: 8th day or later. GR: good recovery, MD: moderate disability, SD: severe disability, PVS: persistent vegetative state, D: death.

*The mortality rate of the elderly patients who was operated on in the acute stage is higher than that in delayed surgery ( $<<0.05$, Chi-square test).

Fig. 2 Distribution of Glasgow Outcome Scale at discharge according to the period of surgery

かった(Fig. 1)．ただ，高齢者の Grade IV 患者 8 名の転帰 はすべて GOS：SD 以下で，若年者では 11 名のうち転帚 良好例 (GOS：GR, MD) が 5 例 (45\%) あったのと対照的 であった。

手術時期 (Fig. 2) では, 発症後 3 日以内 (急性期) に 24 例 (60\%) が手術され，4 日〜 7 日 (亜急性期) 5 例 (10\%), 8 日以後 (待機) 13 例 $(30 \%)$ であった。手術時期と ADL との関係を見ると，急性期手術でやや転帚不良であるが，
有意差はなかった。しかし，死亡率は，急性期手術群が待 機手術群より悪かった $(42 \%$ と $8, p<0.05)$. 若年者群 では, ADL, 死亡率ともにどの群の間にも有意差はなか った.

また，動脈瘤の部位別に転帰を比較すると，前大脳動脈 遠位部動脈瘤症例では高齢者に有意に悪かった $(p<0.05)$. 症例数は少ないが, 高歯者群では入院時に全例意識障害を 伴い，若年者群より grade が悪かったことによると思われ 
Table 4 Primary causes of poor outcome (SD, PVS, D)

\begin{tabular}{ccccccc}
\hline Group & SAH & Rebleeding & Vasospasm & Op. & Sys. & Total \\
\hline Eldery & $8(4)$ & $3(1)$ & $7^{*}\left(2^{*}\right)$ & $3(1)$ & $3(3)$ & $24(11)$ \\
Young & $2(1)$ & $2(2)$ & $13^{*}\left(9^{*}\right)$ & $2(0)$ & $1(1)$ & $20(13)$ \\
\hline
\end{tabular}

SAH: initial subarachnoid hemorrhage, Op.: operative procedures, Sys.: systemic complications.

Number in parenthesis indicates the number of dead cases.

*Vasospasm in the young group is significantly more than in the elderly group. $(p<0.05$, Chi-Square test)

\section{た．他の部位では転帰に差は見られなかった。}

転帰不良 $(\mathrm{GOS}: \mathrm{SD}$ 以下) となった直接の原因は，若年 者ではほとんどが脳血管攣縮と考えられたのに対し，高齢 者では初回出血の直接の影響, 脳血管攣縮が 2 大要因であ った (Table 4)．死亡原因ではさらに全身合併症が加わっ た. Grade III患者の悪化原因は，若年者で再破裂を除けば すべて血管攣縮によるものであったのに対し，高齢者では 血管攣縮は 10 例中 4 例にすぎず，全身の合併症 (肺炎，消 化管出血) や手術の合併症 (脳梗塞) も各々 2 例と多かった. また，Grade IV患者は全例転帰不良であったが，その原因 は初回出血の影響 5 例, 脳血管攣縮 2 例, 再破裂 1 例であ った。

\section{考察}

かつては高齢者の手術成績が悪く, 高齢というだけで手 術適応外と考えられたこともあった ${ }^{5)}{ }^{14)}$ が，保存的治療の 予後も非常に悪く，また一方で麻酔や術前後の全身管理の 技術が進歩することにより, 最近では, 積極的に手術が行 われるようになってきた。

また，平均寿命の延びにともなった高齢化と共に高齢者 の定義自体にも変化が見られている.すなわち，1980年代 前半までは 60 歳以上を高齢としていた 10) 16) となり，1990年代にはいると 70 歳で区切られること が多くなってきた ${ }^{711) 17) 18) . す な わ ち, ~ I n a g a w a ~}{ }^{2)}$ が述べ ているように，60歳代でも，かつての 50 歳代と同じ成績 を挙げられるようになってきている。したがって，高齢者 の検討をする際には 70 藏以上を対象として考えるのがよ いと思われる。

高齢者破裂脳動脈瘤症例の特徵として一般に認められて いることは, 若年者と比べて, 女性に多い, 入院時 grade が悪く, 予後も悪いなどである. 今回の検討でも同様の結 果が得られたが，入院時 gradeに関しては，手術症例では 悪かったが，overall で見ると若年者と差はなかった。こ れは安井らの報告 ${ }^{18)}$ と逆の結果となったが，当院では患 者の過半数が他院からの紹介患者であり, 状態の悪い患者 の場合転送されない可能性もあり, 特に高齢者では grade
の悪い患者が漏れやすいと考えられた.

動脈瘤の部位は，内頸動脈に多く，前交通動脈に少ない とする報告が多い，我々の例では内頸動脈，前交通動脈と もに少なかったが，特に有意差はなかった．部位別の転帰 では, 前大脳動脈遠位部の動脈瘤で grade, GOS ともに有 意に悪かった。このような報告はこれまで見当たらず，症 例数は少ないが, 高齢者ではクモ膜下出血の程度が強く, 脳内出血をともなうなど，若年者とは明らかに異なって打 り, 今回の同部位動脈瘤の一つの特徵であると思われた。 その他の部位では差はなかった。

手術は，できる限り早期に行う方針としているが，入院 時期や全身状態不良のため, やむを得ず待機手術とした例 もあり，こうした症例は若年者群より多かった，急性期手 術と待機手術の比較は困難で, 一般に, 待機手術の報告の 方が良い成績であるが，全例待機手術とすることが困難な ことや，待機中に悪化する例などの脱落例があるため，一 概には言えない，今回も，Grade IV,Vではほとんど急性 期に手術が行われているため, 死亡率では明らかに手術時 期による差があり, 転帰全体では有意差は得られなかった ものの，急性期手術の予後は不良であった。

脳血管攣縮については、高齢者に多いという報告 ${ }^{1116)}$

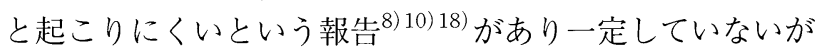
予防的治療がうまく行えるかどうかに左右されていると考 える者もある ${ }^{6)}$. 共通していることは, 症候性血管攣縮を 起こせば症状は恒久的になりやすく，また一方，脳血管攣 縮は若年者では予後不良となる一番の原因であるが, 高齢 者では全身の合併症や手術操作の影響も大きく, 多くの要 因を乗り越えなくてはならない。このためにも最小限の手 術侵襲 (手術時間の短縮, approach の工夫, 最小限の temporary clip の使用など) や術後の早期離床・早期から のリハビリなどについて若年者以上に留意する必要がある.

手術適応に関して, 意識障害のない Grade I, II 患者で は急性期手術がよいことは異論のないところで, 若年者に 近い良好な成績を治めている. Grade IIIでは，かつては急 性期手術の成績が悪く, 待機して状態がよければ手術する という考え方が多かった ${ }^{799}$ が, 次第に若年者同様, 早期 
手術が主流となっている. しかし，脳血管攣縮以外の原因 で転帰不良となることも多く, 神経系だけでなく, 循環 器・呼吸器系を含めた全身機能, 予備能を考えると, 若年 者と同等の成績を収めることは難しいかもしれない.さら に，Grade IV患者に関してはいまだ議論の多いところで, 貫井ら ${ }^{8)}$ は急性期手術を行っているが，年齢が 65 歳まで で脳内出血も小さいものと限定し, 矢野ら ${ }^{17)} も$ 場合によ り適応となるが,「より慎重な考慮が必要」であると述べ ている，最近の報告でも，Grade IV は予後不良であり ${ }^{18)}$, またWFNS Grade III 以下では良好な転帰は望めないとす る報告が多い11)12)。このように高齢者の Grade IV 患者の 手術に関しては悲観的な考え方が多く，今回の検討でも同 様の結果で, 初回出血から改善することなく経過した例が ほとんどである，さらに長期予後を検討すると，退院時に 介助を要する状態では ADL が悪化していくことが多く, 特に高齢者ではほとんどが死亡している ${ }^{15)}$ 。しかしなが ら, 術前後の管理, 血管攣縮の治療などにより改善が望め る例もあり, 発症前の全身状態も考慮にいれ手術適応を決 めるべきであり，いかに予後の改善をはかるか，今後の課 題であり，血管内手術など新しい治療法にも期待したい.

\section{文献}

1) Hunt WE, Kosnik EJ: Timing and perioperative care in intracranial aneurysm surgery. Clin Neurosurg 21: 79-89, 1974

2) Inagawa T: Management outcome in the elderly patient following subarachnoid hemorrhage. J Neurosurg 78: 554561, 1993

3) Jennett B, Bond M: Assessment of outcome after severe brain damage. A Practical Scale. Lancet i : 480-484, 1975

4) Jomin M, Lesoin F, Lozes G: Prognosis with ruptured and operated intracranial arterial aneurysms. Surg Neurol 21:
$13-18,1984$

5) Martindale BV, Garfield J: Subarachnoid hemorrhage above the age of 59: Are intracranial investigations justified? Br Med J 25: 465-466, 1978

6）長澤史朗, 大槻宏和, 米川泰弘, ほか：高齢者破裂脳動脈 瘤 60 例の検討. 脳神経外科 16: 17-21, 1988

7）新妻 博, 吉本高志, 鈴木二郎：70 歳以上の高齢者の脳動 脈瘤根治手術例 35 例の検討。脳卒中 7: 219-223, 1985

8）貫井英明, 金子的実, 三塚 繁：高齢者破裂脳動脈瘤症例 における手術成績とそれに基ずく手術適応. Neurol Med Chir (Tokyo) 25: 275-281, 1985

9) Ohmoto T, Mino S, Nishimoto A, et al: Operative results of ruptured intracranial aneurysms in aged patients. Neurol Med Chir (Tokyo) 20: 721-728, 1980

10）岡一成, 黑松千春, 高木東介, ほか：高齢者脳動脈瘤治 療の問題点. 脳神経外科 15: 375-379, 1987

11）小野純一，山上岩男，礒部勝見，ほか：高齢者破裂脳動脈 瘤急性期手術例における管理上の問題点. 脳卒中の外科 21: 239-245, 1993

12) O'Sullivan MG, Dorward N, Whittle IR, et al: Management and long-term outcome foilowing subarachnoid haemorrhage and intracranial aneurysm surgery in elderly patients: An audit of 199 consecutive cases. Br J Neurosurg 8: 23-30, 1994

13）桜井芳明, 荒井啓晶：宮城県におけるクモ膜下出血のき 療 成績。脳外誌 4: 207-212, 1995

14) Shephard RH: Ruptured cerebral aneurysms: Early and late prognosis with surgical treatment. A personal series, 1958-1980. J Neurosurg 59: 6-15, 1983

15）柴田裕次, 野垣秀和, 田村昌吾：〈も膜下出血患者の長期 予後について。第 53 回 日本脳神経外科学会総会抄録集, 1994, p 117

16）鈴木明文, 安井信之, 波出石弘, ほか：高齢者破裂脳動脈 瘤急性期手術例の術前重症度の検討. Neurol Med Chir (Tokyo) 28: 1152-1156, 1988

17）矢野 隆，川上哲二,上家和子, ほか：高齢者破裂脳動脈 瘤患者の検討. 脳卒中 8: 231-236, 1986

18）安井敏裕, 矢倉久嗣, 小宮山雅樹, ほか：高齢者破裂脳動 脈瘤の治療方針。脳神経外科 20: 651-656, 1992 